DOI: https://doi.org/10.15688/nav.jvolsu.2020.2.1

UDC 902.01(042)

Submitted: 22.06 .2020

LBC 63.401я43

Accepted: 24.11 .2020

\title{
ANATOLY S. SKRIPKIN \\ AND MY GENERATION OF SARMATOLOGISTS
}

\author{
Alexandr P. Medvedev \\ Voronezh State University, Voronezh, Russian Federation
}

\begin{abstract}
The article is dedicated to the $80^{\text {th }}$ anniversary of Anatoly S. Skripkin, professor of the Volgograd State University. It is based on the authors personal memories about several important milestones in the biography of this eminent scientist. His great contribution to the modern Russian sarmatology is assessed.

Key words: Volgograd, Anatoly Stepanovich Skripkin, Russian archaeologists, Asian Sarmatia, sarmatology.

Citation. Medvedev A.P., 2020. Anatoliy Stepanovich Skripkin i moe pokolenie sarmatologov [Anatoly S. Skripkin and My Generation of Sarmatologists]. Nizhnevolzhskiy Arkheologicheskiy Vestnik [The Lower Volga Archaeological Bulletin], vol. 19, no. 2, pp. 8-17. DOI: https://doi.org/10.15688/nav.jvolsu.2020.2.1
\end{abstract}

УДК 902.01(042)

Дата поступления статьи: 22.06.2020

ББК 63.401 я 43

Дата принятия статьи: 24.11.2020

\section{АНАТОЛИЙ СТЕПАНОВИЧ СКРИПКИН И МОЕ ПОКОЛЕНИЕ САРМАТОЛОГОВ}

\author{
Александр Павлович Медведев \\ Воронежский государственный университет, г. Воронеж, Российская Федерация
}

Аннотация. Статья посвящена 80-летию профессора Волгоградского государственного университета А.С. Скрипкина. Она написана на основе личных воспоминаний автора о некоторых важных вехах в творческой биографии этого выдающегося ученого. Дается оценка его большого вклада в современную российскую сарматологию.

Ключевые слова: Волгоград, Анатолий Степанович Скрипкин, русские археологи, Азиатская Сарматия, сарматология.

Цитирование. Медведев А. П., 2020. Анатолий Степанович Скрипкин и мое поколение сарматологов // Нижневолжский археологический вестник. Т. 19, № 2. С. 8-17. DOI: https://doi.org/10.15688/nav.jvolsu.2020.2.1

В год Большого Юбилея моего друга Анатолия Степановича Скрипкина, наверное, появится не одна статья, посвященная его научной биографии и оценке огромного вклада у ученого в современную российскую сарматологию. Волгоградские коллеги, безусловно, лучше знают своего профессора, основателя 兽 волгоградской школы сарматологии, которая с 80-х годов заняла лидирующие позиции в изу$\sum^{\varpi}$ чении истории и культуры сарматов. Поэтому () я поставил перед собой более скромную зада- чу - поделиться некоторыми моими воспоминаниями и впечатлениями об А.С. Скрипкине, с которым знаком почти 40 лет. Это своего рода некоторые штрихи к биографии ученого на фоне нашего поколения сарматологов. Его расцвет как раз приходится на 80-90-е годы прошлого века, когда шло становление Анатолия Степановича как признанного неформального лидера отечественной сарматологии.

Имя А.С. Скрипкина я впервые услышал от Константина Федоровича Смирнова в 
1978 г., когда он читал спецкурс по сарматской археологии в нашем университете. В том же году с его благословения я начал раскопки сарматских курганов I Чертовицкого могильника - в общем, стал заниматься сарматами. Но если литературы по савроматам и ранним сарматам, благодаря тому же К.Ф. Смирнову и М.Г. Мошковой, было немало, то по среднеи позднесарматской культуре в конце 70-х годов прошлого века ощущался ее явный дефицит. Пришлось поехать на стажировку в Москву, где в Архиве Института археологии я получил доступ к неопубликованной кандидатской диссертации А.С. Скрипкина по позднесарматской культуре Нижнего Поволжья (издана в 1984 г.). Диссертация и особенно приложение с рисунками к ней были изучены мной весьма основательно. Они позволили мне досконально познакомиться с керамикой, фибулами и другими характерными элементами позднесарматской культуры. Вскоре эти знания очень пригодились мне при раскопках верхнедонских курганных могильников позднесарматского времени в начале 80 -х годов прошлого века.

В 1981 г. от М.Г. Мошковой я узнал, что в Волгограде готовится к изданию сборник научных работ, посвященный памяти К.Ф. Смирнова. Она дала мне адрес А.С. Скрипкина и посоветовала направить ему статью по сарматской археологии - благо к этому времени нового материала у меня было много. Я так и сделал - отправил статью в сборник «История и культура сарматов» (Саратов, 1983), но к стыду своему исказил отчество Скрипкина - обратился к нему как к Анатолию Аркадьевичу. Вскоре получил вежливый ответ статья в сборник принята, а ниже приписка «Анатолий Степанович Скрипкин». Заочное знакомство состоялось. А через год мы встретились на семинаре в Секторе скифо-сарматской археологии, который тогда еще находился в подвале Института археологии.

Следующий эпизод - конференция в $\mathrm{Ca}$ ратове в 1984 г., посвященная 100-летию со дня рождения П.С. Рыкова. Помню, что мы заседали в очень холодном красном здании в центре Саратова, но, несмотря на холод, наша сарматская секция была весьма представительной и работала активно. Безусловно, главным событием конференции для нас стал доклад А.С. Скрипкина о новой хронологии ран- не- и среднесарматской культуры, где он очень убедительно доказал, что рубеж между ними надо сдвинуть, как минимум, на век - ближе к рубежу эр. Сейчас это воспринимается как само собой разумеющийся факт, но до окончательного утверждения этой новации потребуется по меньшей мере еще десятилетие.

Не скрою, для меня этот доклад был как бальзам на душу. Дело в том, что годом раньше я представил в скифо-сарматский сектор рукопись кандидатской диссертации, где датировал среднесарматские Чертовицкие могильники I - началом II в. н.э. Такая узкая датировка вызвала принципиальное возражение сотрудников сектора, поскольку среднесарматскую культуру тогда было принято датировать более широко - от рубежа II-I вв. до н.э. до середины II в. н.э. Но в лесостепном Подонье мне не удалось найти ни одного среднесарматского погребения со сколь-нибудь определенными материалами ранее рубежа эр. Поэтому, несмотря на критику старших коллег, я остался при своем мнении, что и нашло отражение в автореферате моей кандидатской диссертации.

Надо отметить, что к середине 80-х годов в сарматской археологии сложилась уникальная ситуация. После кончины Константина Федоровича Смирнова в 1980 г. она, так сказать, оказалась без абсолютного авторитета. С другой стороны, к этому времени на периферии о себе заявило новое поколение археологов, уже прочно ставших на ноги и защитивших кандидатские диссертации. К старшей его генерации, помимо А.С. Скрипкина, принадлежали Борис Федорович Железчиков из Волгограда (1946-2000) и ростовчанин Владимир Евгеньевич Максименко (1939-2014). Моими ровесниками ( \pm несколько лет) были: Борис Аронович Раев из Ленинграда, Александр Владимирович Симоненко из Киева, Владимир Иванович Костенко из Днепропетровска (19491996), Александр Михайлович Ждановский, а чуть позже к нам присоединился Иван Иванович Марченко (оба из Краснодара). Сформировалось некое неформальное сарматское братство, какого я, признаюсь, не наблюдал ни в классической античной археологии, ни в скифологии. Это отнюдь не означает, что наши конференции и семинары проходили бесконфликтно - были жаркие научные дискуссии, иног- 
да спор доходил до того, что докладчик прерывал выступление и спешил в библиотеку за дополнительными аргументами. Но вечером мы все дружно собирались в одном из тесных гостиничных номеров, и как раз там разворачивалась наиболее интересная и продуктивная часть конференции.

Следует напомнить, что помимо традиционной Нижнедонской археологической конференции в то время мы регулярно встречались на семинаре «Античная цивилизация и варварский мир», организованном Б.А. Раевым. Разумеется, тон в нем задавали сарматологи, хотя с интересными докладами выступали и скифологи, и антиковеды. На одном из таких семинаров случился эпизод, который, как мне кажется, мог в одночасье прервать расцвет российской сарматской археологии.

Как было принято на семинаре у Б.А. Раева, один день отводился на экскурсию. Весной 1988 г. Боря повез нас на базу его экспедиции в д. Озерки - там, у старой хижины, уже был накрыт стол, мы хорошо посидели, подискутировали, было произнесено много тостов. Еще засветло вернулись в Новочеркасск к гостинице, и многие почувствовали, что чего-то важного явно не хватает. Тут в мановение ока оказалась старая грузовая экспедиционная машина, за ее рулем сидел незабвенный Женя Беспалый, которого, к сожалению, с нами давно уже нет. Кто предложил продолжить семинар на другой базе в хут. Мишкин, я, откровенно говоря, не помню. Но сарматский народ вдруг стал активно залезать в кузов машины... без тента и номеров, и она тронулась. Я сидел рядом с А.С. Скрипкиным и, думаю, испытал те же эмоции, что и он, когда на трассе за Новочеркасском нас пытались задержать сотрудники ГАИ на «Волге», и как мы уходили от погони вдоль лесополосы почти по свежей пахоте на машине, которая, казалось, от тряски вотвот развалится. А по другой стороне лесополосы по накатанной дороге ехала милицейская машина. В какой-то момент Женя высунулся из окна кабины и успокоил нас, что скоро наши преследователи остановятся, так как хорошая дорога перекопана. В общем, в хут. Мишкин мы прибыли благополучно.

А дальше был один из самых интересных вечеров (или ночей) в моей научной жизни. Среди нас оказался один довольно моло- дой, но заводной человек по фамилии Кочубей (имя, к сожалению, уже не помню). Он начал рассказывать о своих необычных раскопках в Западном Казахстане, где якобы открыл погребение воина в пластинчатом панцире, заколотом на плече... фибулой. Тут же почти в один голос завзятые вещеведы - Анатолий Степанович и оказавшийся в нашей компании Марк Борисович Щукин - задали один и тот же вопрос: что это была за фибула, какого типа? После долгого, но невразумительного ее описания, отвечая на наводящие вопросы, Кочубей взял со стола обычную алюминиевую ложку и коротко ответил: «Вот такая!» Завязавшаяся дискуссия о фибулах и о многом другом продолжалась почти до рассвета. Незаметно в какой-то момент дело дошло до того, что мы даже решили принять в партию... Б.А. Раева, чтобы он мог стать директором Новочеркасского музея (это были годы «перестройки» и в партию можно было вступить легко, даже с Бориной национальностью). Впрочем, об этом уже писал один из участников нашего «легендарного» ночного заседания А.В. Симоненко в предисловии к сборнику Б.А. Раева, посвященному его шестидесятилетию. Наутро мы благополучно вернулись в Новочеркасск и сфотографировались перед зданием гостиницы (первая черно-белая фотография).

А осенью того же 1988 г. в г. Новочеркасске наконец-то состоялась I конференция по археологии и культуре сарматов, к которой мы готовились лет пять. Одним из ее активных инициаторов был А.С. Скрипкин. Заранее мы обговорили и поделили темы докладов, чтобы они охватили все проблемы сарматологии. Доклады были изданы в виде сборника и разосланы участникам конференции до ее начала, так что докладчики не столько выступали, сколько отвечали на вопросы, возникшие у коллег при внимательном прочтении текстов выступлений. Среди серии докладов своей концептуальностью и основательностью выделялся доклад А.С. Скрипкина «Азиатская Сарматия: проблемы истории и культуры», который по существу представлял основные тезисы его будущей докторской диссертации, защищенной в 1992 году. Этот доклад содержал новаторскую идею формирования и развития всех сарматских культур в результате 
сложного процесса взаимодействия традиций и инноваций. По мнению А.С. Скрипкина, преемственность между ними обеспечивает сохранение старого населения, отдельные элементы культуры которого иногда могут получить значительное распространение в рамках уже новой культуры, признаки, определяющие лицо новой культуры, привносятся в результате новых миграций. На мой взгляд, эта универсалия прослеживается не только в сарматских, но практически во всех степных кочевых культурах вплоть до развитого Средневековья. I Сарматская конференция прошла весьма удачно. Было решено продолжить это начинание, а в сентябре 2019 г. в г. Севастополь (Херсонес) состоялась уже юбилейная $\mathrm{X}$ Международная сарматская конференция.

90-е годы ознаменовались появлением работ А.С. Скрипкина по «восточной тематике». Он один их первых обратил внимание на присутствие в ранне-, средне- и позднесарматской культурах целых пучков восточных элементов, связанных по происхождению с древними цивилизациями вплоть до Китая. Об этом писали и другие сарматологи. Но в отличие от них А.С. Скрипкин получил уникальную возможность не только посетить Китай, но и пожить там, изучить богатые коллекции музеев, содержащие прототипы артефактов, которые ранее у нас было принято считать собственно сарматскими. Уже в начале этого тысячелетия «восточные штудии» А.С. Скрипкина вошли в его книгу «Сарматы и Восток».

Вершиной научного творчества професcopa А.С. Скрипкина стала его итоговая монография с коротким названием «Сарматы», изданная в Волгограде в 2017 году. Она явилась не только результатом его многолетних исследований, но и глубоким обобщением разработок различных проблем сарматской археологии и истории другими российскими и зарубежными исследователями. В этом смысле, на мой взгляд, сарматологам, особенно начинающим свой путь в науке, повезло, как в свое время повезло скифологам после издания в 1971 г. Б.Н. Граковым книги «Скифы». Монография A.С. Скрипкина - первый обобщающий труд по всей сарматской археологии, которая в силу внутренних законов развития науки становится все более дифференцированной. Сочинение было долгожданным и сразу стало настольной книгой не только российских сарматологов, но и всех специалистов по археологии раннего железного века Юга Восточной Европы.

А.С. Скрипкин, пожалуй, единственный современный исследователь, который с одинаковым результатом занимается изучением разных периодов всех сарматских культур. Через всю его книгу красной нитью проходит главная мысль, наметившаяся еще в его тезисах 1988 г., о некоем универсальном алгоритме в формировании всех сарматских культур. Он заключался в том, что каждая их них складывалась в результате сложного взаимодействия инноваций, привнесенных с востока новыми волнами номадов, и традиций, оставленных местным населением, причем без каких-либо существенных хиатусов, которые предполагались еще совсем недавно. Как по объему затронутых в монографии проблем, так и по глубине их решения книга не имеет аналогов в отечественной или зарубежной науке. Отмечу, что по структуре и стилю видно - она написана университетским профессором, посвятившим более полувека не только изучению, но и преподаванию студентам археологии и истории сарматов.

И последнее. Так уж случилось, что благодаря А.С. Скрипкину сложились тесные отношения между археологами Волгоградского и Воронежского университетов. В диссертационном совете при нашем университете защищали кандидатские диссертации многие его ученики. В свою очередь, Волгоградский университет по понятным причинам чаще всего выступал в качестве ведущей организации по диссертациям моих учеников. Воронежские археологи с удовольствием публиковали свои статьи в основанном А.С. Скрипкиным «Нижневолжском археологическом вестнике». Это плодотворное сотрудничество продолжается и поныне.

Дорогой Анатолий Степанович! Для меня Вы мудрый старший наставник, доброжелательный человек, с которым всегда приятно и интересно общаться. В год Большого Юбилея я и мои воронежские коллеги желают Вам старейшине российских сарматологов - добра, здоровья, новых творческих удач и открытий. В качестве скромного подарка примите фотографии разных лет с вашим участием, которые нашлись в моем фотоархиве. 


\section{ИЛЛЮСТРАЦИИ}

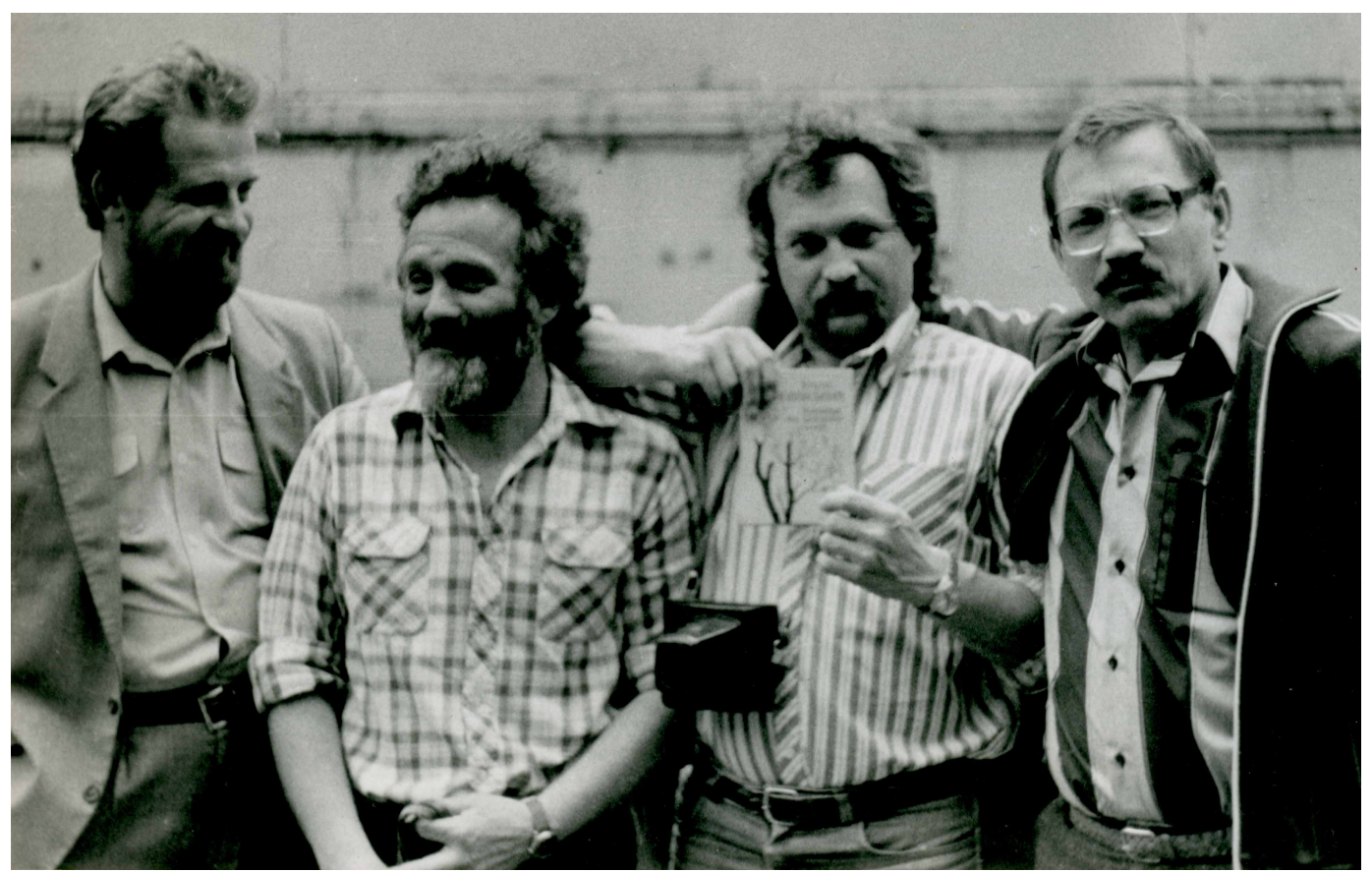

Цвет сарматской археологии после ночного заседания в хут. Мишкин.

Слева направо: А.П. Медведев, Б.А. Раев, А.В. Симоненко, А.С. Скрипкин. Новочеркасск, 1988 г.

The cream of Sarmatian archaeology after the night-time session in the village of Mishkin. From left to right: Alexander Medvedev, Boris Rayev, Alexander Simonenko, Anatoly Skripkin. Novocherkassk, 1988

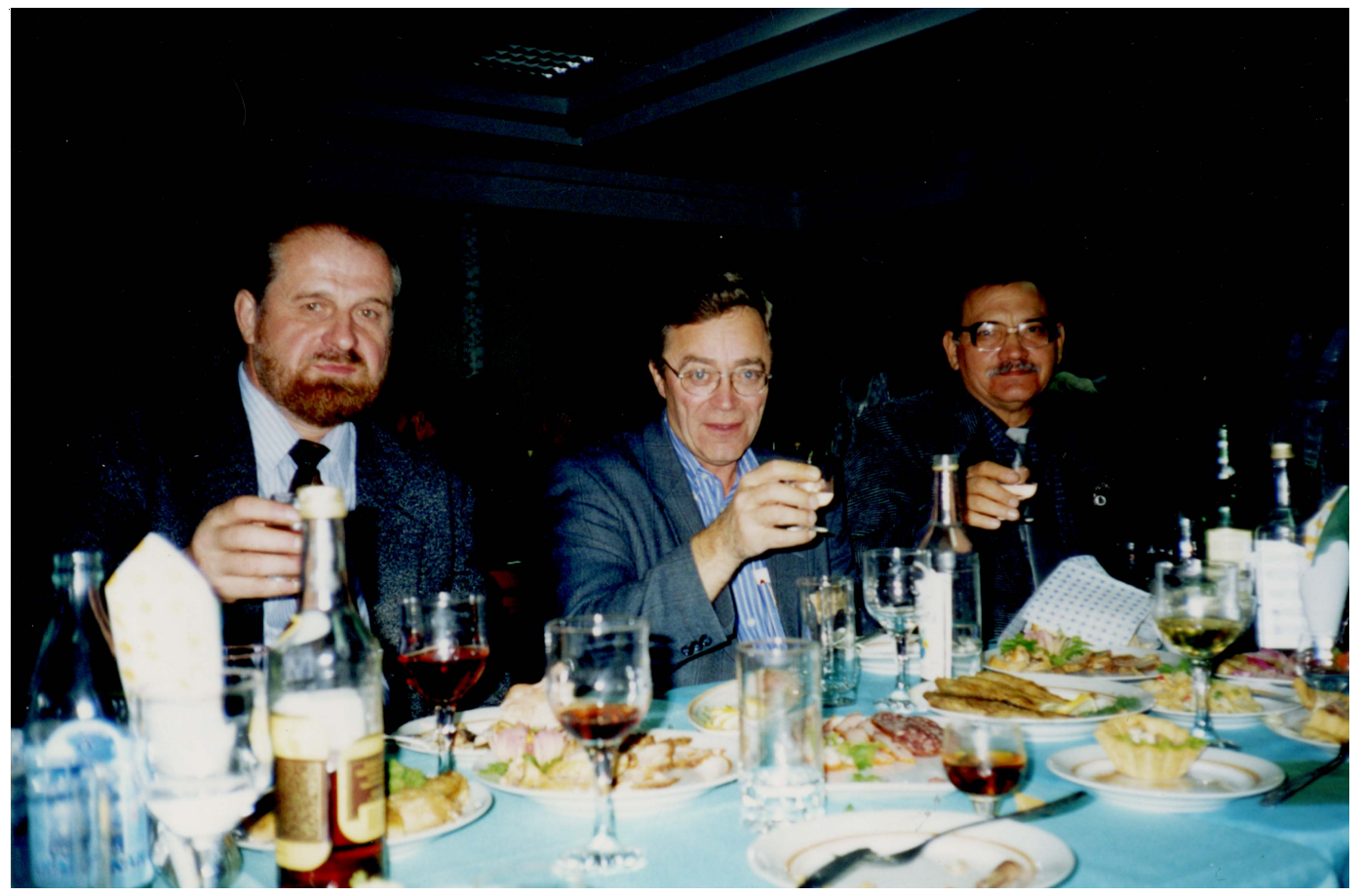

На банкете 3-й Кубанской археологической конференции.

Слева направо: А.П. Медведев, А. Наглер, А.С. Скрипкин. Анапа, 2000 г.

At the banquet of the $3^{\text {rd }}$ Archaeological Conference of Kuban.

From left to right: A. Medvedev, A. Nagler, A. Skripkin. Anapa, 2000 


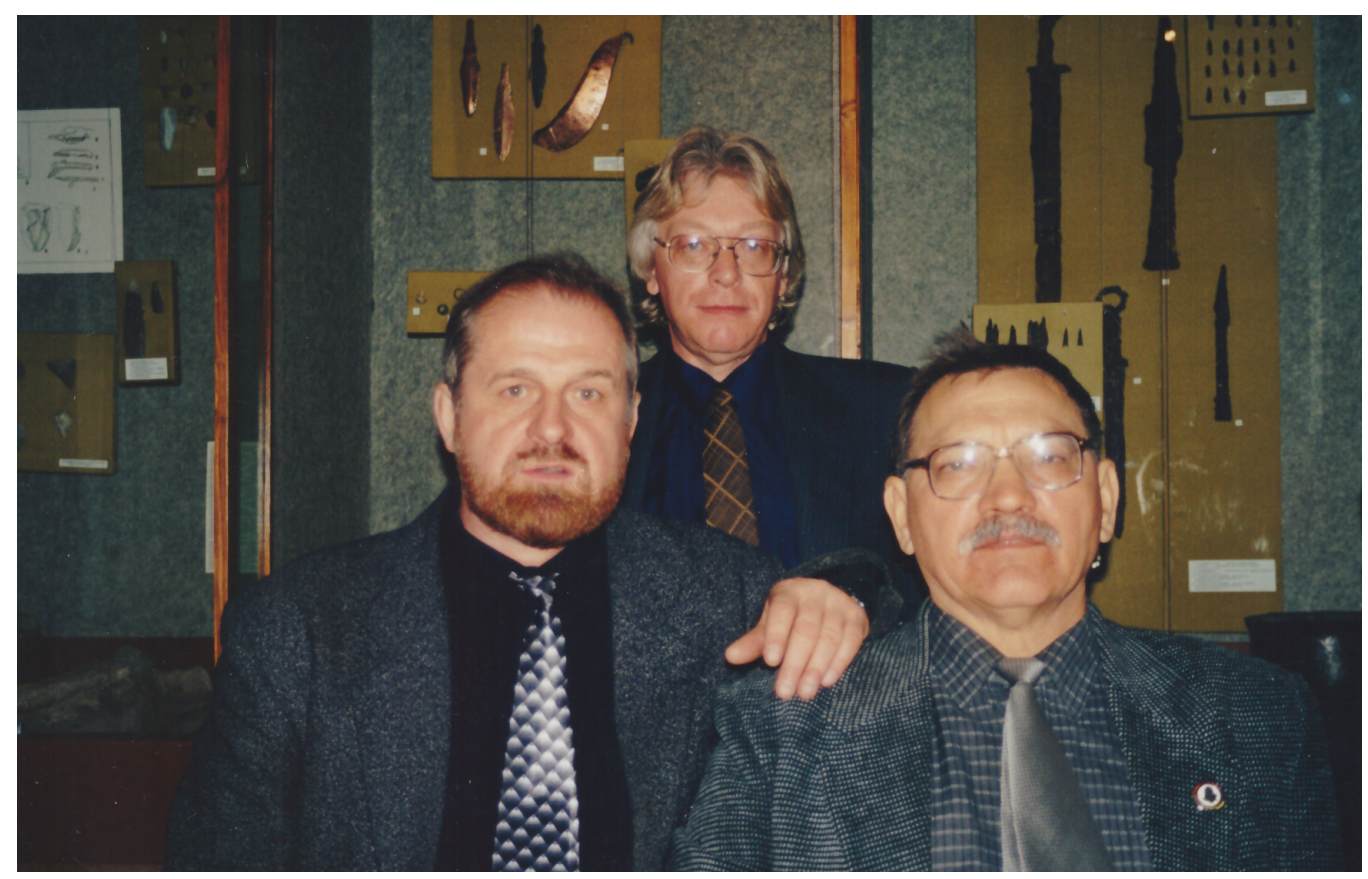

Перед защитой А.А. Глухова.

Слева направо: А.П. Медведев, И.В. Сергацков, А.С. Скрипкин. Волгоград, 2002 г.

Before A. Glukhovs viva voce.

From left to right: A. Medvedev, I. Sergatskov, A. Skripkin. Volgograd, 2002

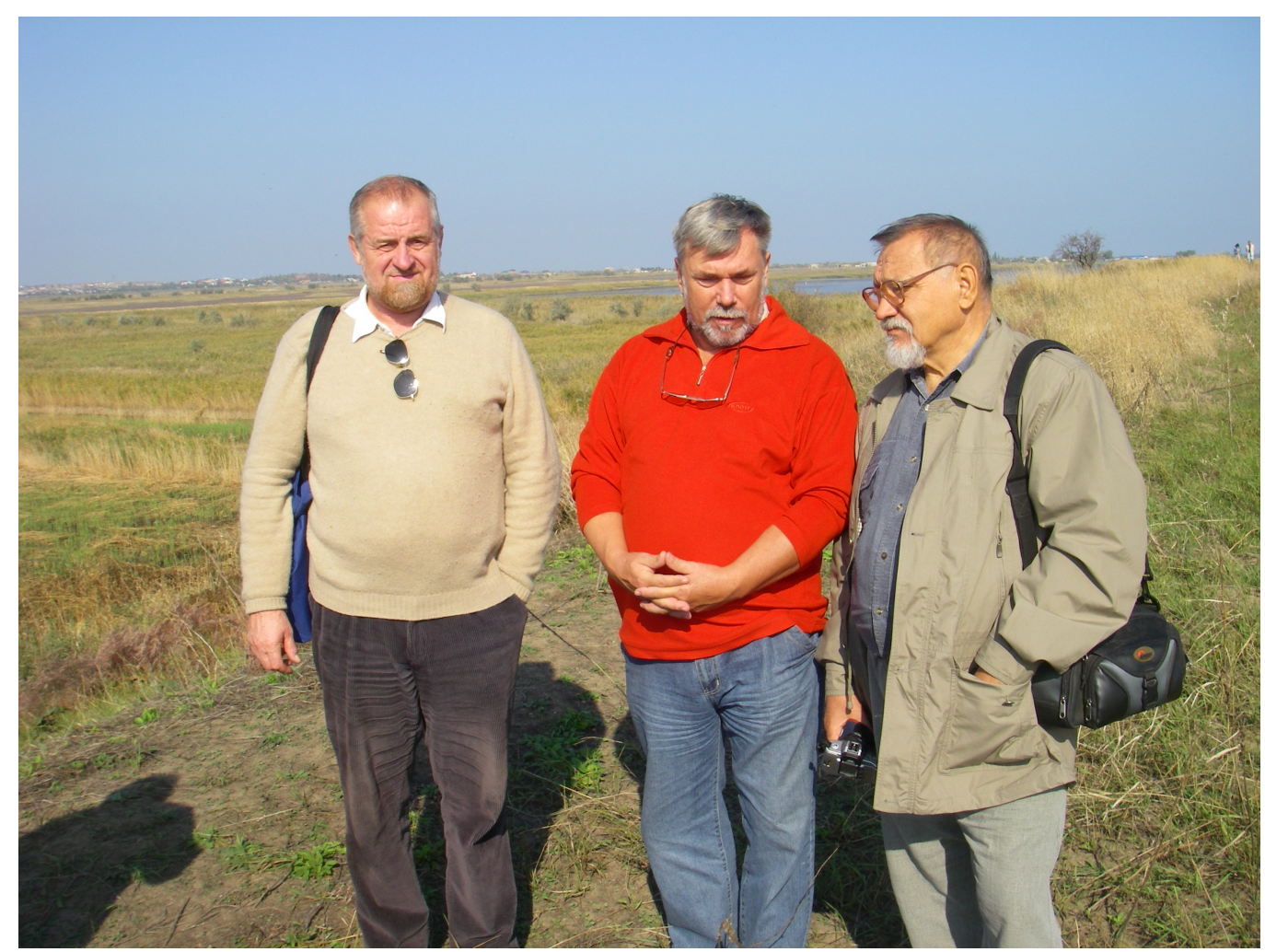

Экскурсия после 5-й Кубанской археологической конференции.

Слева направо: А.П. Медведев, С.И. Лукьяшко, А.С. Скрипкин. Голубицкая, 2010 г.

Sightseeing tour after the $5^{\text {th }}$ Archaeological Conference of Kuban.

From left to right: A. Medvedev, S. Lukyashko, A. Skripkin. Golubitskaya, 2010 


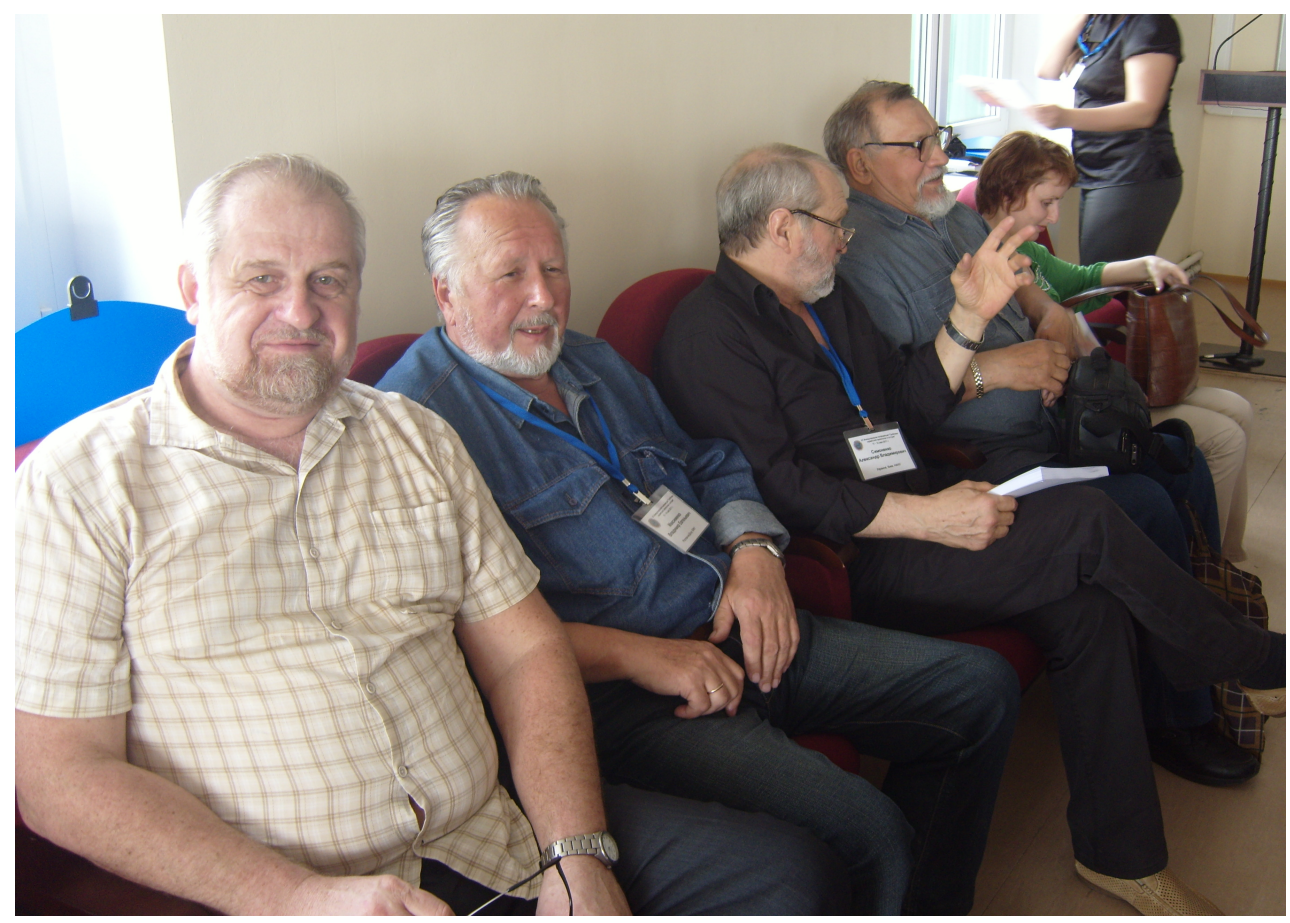

VII Сарматская конференция.

Слева направо: А.П. Медведев, В.Е. Максименко, А.В. Симоненко, А.С. Скрипкин. Ростов-на Дону (Кагальник), 2011 г.

The $7^{\text {th }}$ Sarmatian Conference.

From left to right: A. Medvedev, V. Maximenko, A. Simonenko, A. Skripkin. Rostov-on-Don (Kagalnik), 2011.

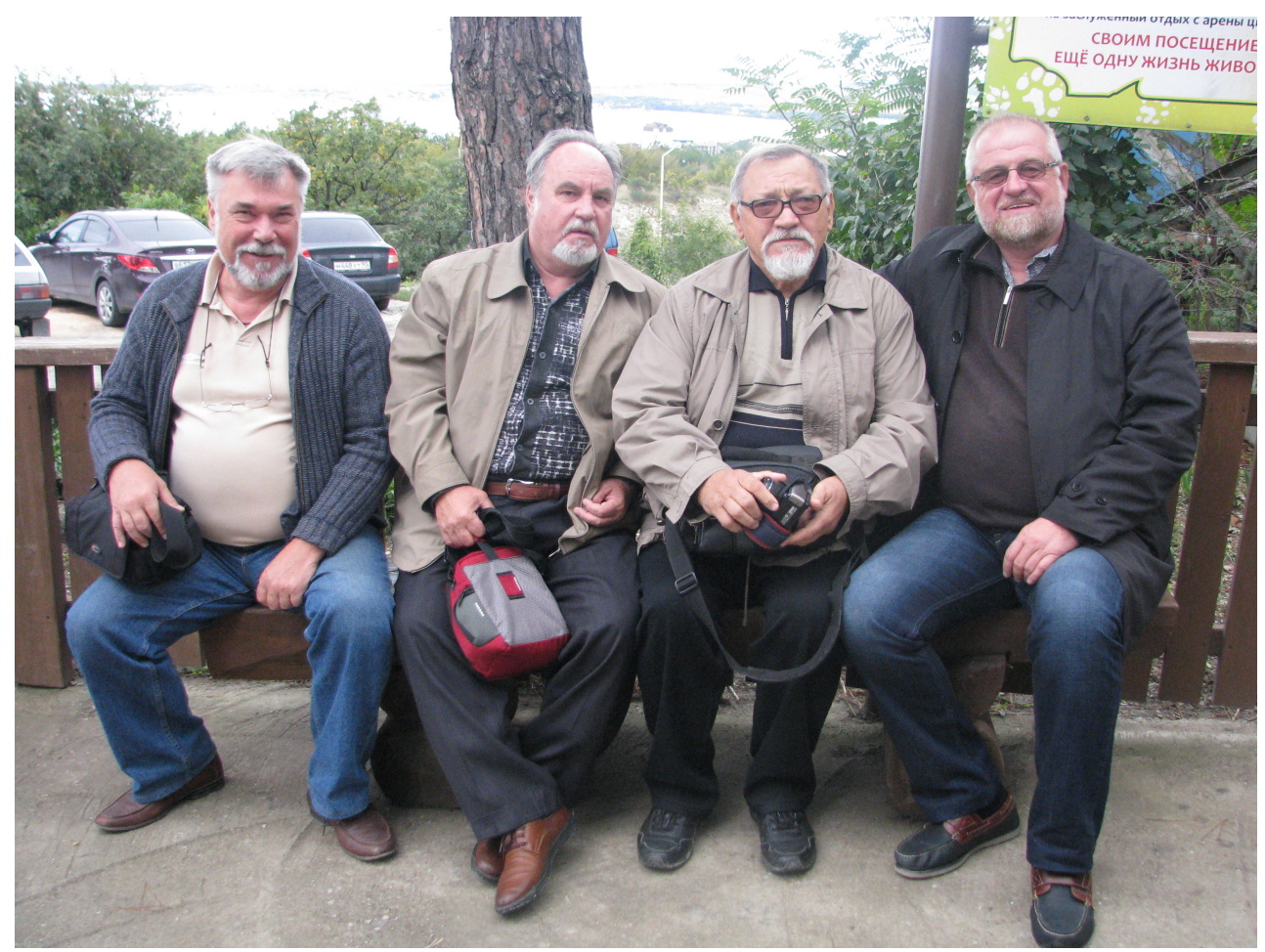

VI Кубанская археологическая конференция под Новороссийском.

Слева направо: С.И. Лукьяшко, А.Н. Подушкин, А.С. Скрипкин, А.П. Медведев. Геленджик, 2013 г.

The $6^{\text {th }}$ Archaeological Conference of Kuban near Novorossiysk.

From left to right: S. Lukyashko, A. Podushkin, A. Skripkin, A. Medvedev. Gelendzhik, 2013 


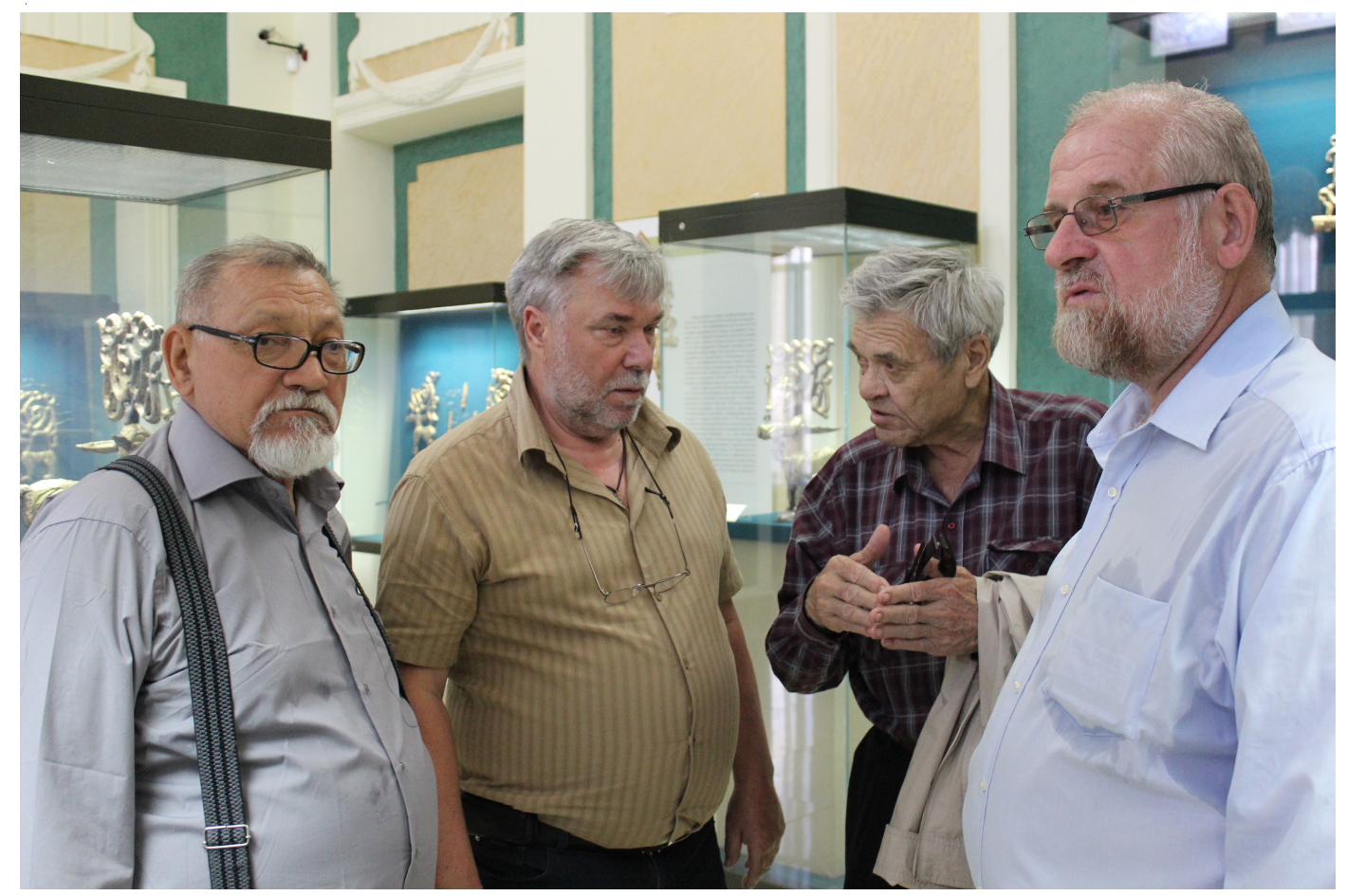

VIII Сарматская конференция в Золотой кладовой с филипповскими оленями.

Слева направо: А.С. Скрипкин, С.И. Лукьяшко, А.Х. Пшеничнюк, А.П. Медведев. Уфа, 2014 г.

The $8^{\text {th }}$ Sarmatian Conference. In the Gold Room with the golden deer from Filippovka.

From left to right: A. Skripkin, S. Lukyashko, A. Pshenichnyuk, A. Medvedev. Ufa, 2014.

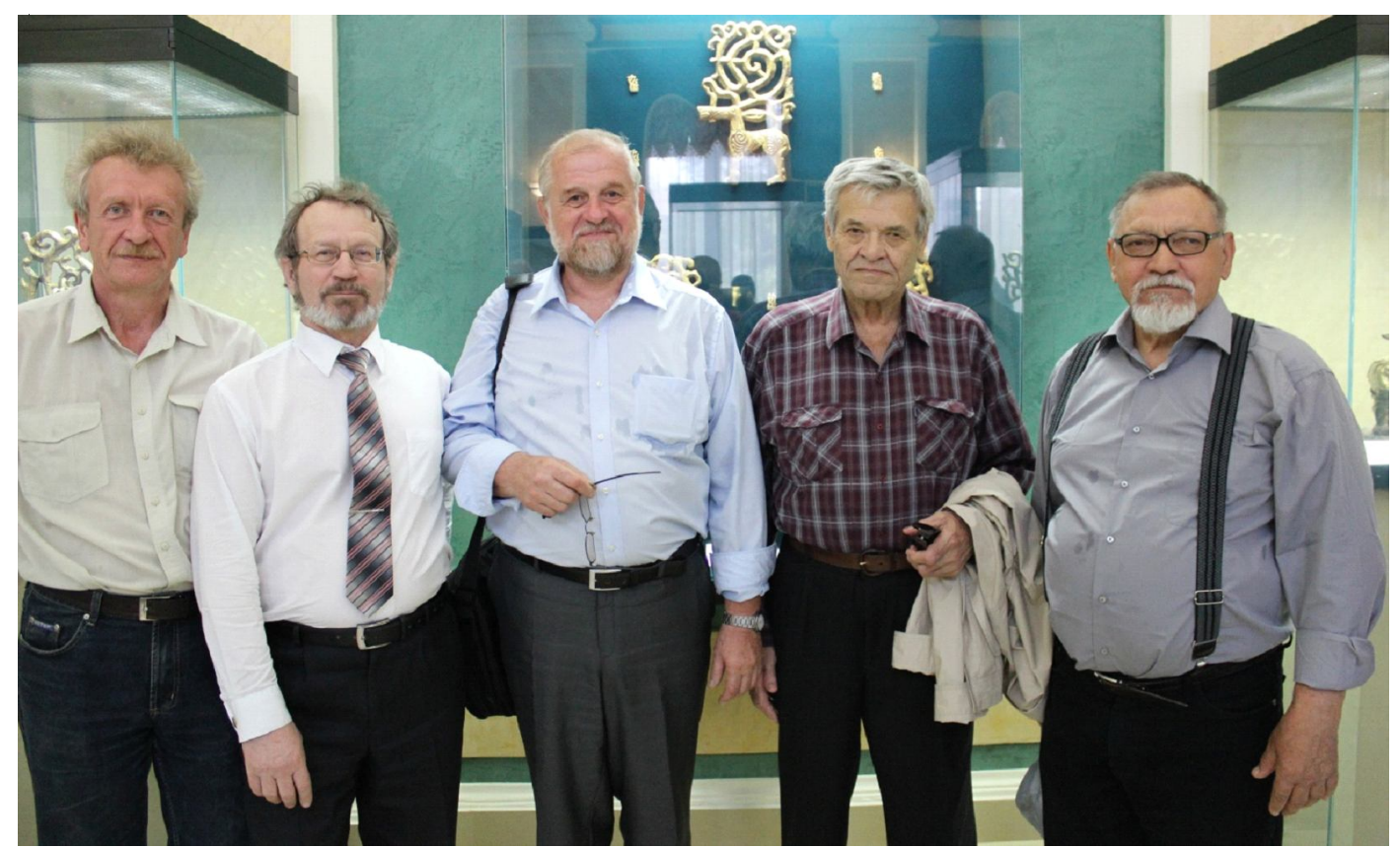

VIII Сарматская конференция в Золотой кладовой с филипповскими оленями.

Слева направо: С.Э. Зубов, А.Д. Таиров, А.П. Медведев, А.Х. Пшеничнюк, А.С. Скрипкин. Уфа, 2014 г. The $8^{\text {th }}$ Sarmatian Conference. In the Gold Room.

From left to right: S. Zubov, A. Tairov, A. Medvedev, A. Pshenichnyuk, A. Skripkin. Ufa, 2014 
A.P. Medvedev. Anatoly S. Skripkin and My Generation of Sarmatologists

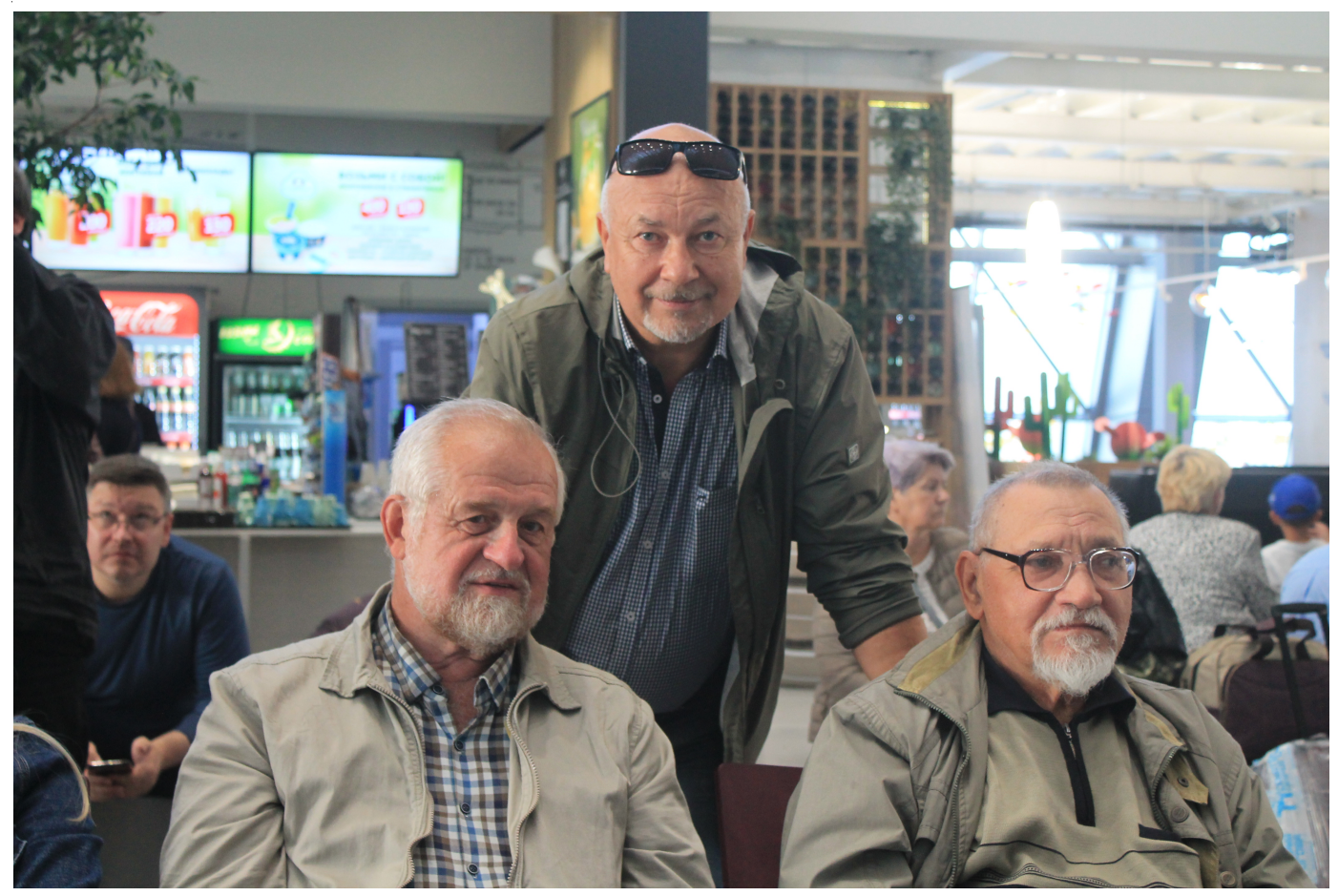

Х Сарматская конференция.

Слева направо: А.П. Медведев, В.Д. Березуцкий, А.С. Скрипкин. Херсонес, 2019 г.

The $10^{\text {th }}$ Sarmatian Conference.

From left to right: A. Medvedev, V. Berezutsky, A. Skripkin.

Chersonesus, 2019. 
А.П. Медведев. Анатолий Степанович Скрипкин и мое поколение сарматологов

\section{Information About the Author}

Alexandr P. Medvedev, Doctor of Science (History), Head of the Archaeology and Ancient History Departament, Voronezh State University, Universitetskaya Sq., 1, 394018 Voronezh, Russian Federation,apm1950@yandex.ru, https://orcid.org/0000-0002-5160-2816

\section{Информация об авторе}

Александр Павлович Медведев, доктор исторических наук, заведующий кафедрой археологии и истории древнего мира, Воронежский государственный университет, Университетская пл., 1, 394018 г. Воронеж, Российская Федерация, apm1950@yandex.ru, https://orcid.org/0000-0002-5160-2816 